\title{
KAPASITAS KOPERTAIS WILAYAH XIII DALAM MENINGKATKAN MUTU PTAIS DI PROVINSI JAMBI
}

\author{
The Capacity of Private Islamic Higher Education Coordinator Region VIII \\ In Improving The Quality of Private Islamic Higher Institution In Jambi Province
}

\author{
Juju Saepudin \\ Balai Penelitian Dan Pengembangan Agama Jakarta \\ Jl. Rawa Kuning No.6 Pulo Gebang Cakung - Jakarta Timur \\ Email: saep.17.khasep@gmail.com
}

Naskah diterima tanggal 10 Juli 2015. Naskah direvisi tanggal 13 september 2015. Naskah disetujui tanggal 03 November 2015.

\begin{abstract}
Abstrak
Penelitian "Kapasitas Kopertais Wilayah XIII Dalam Meningkatkan Mutu PTAIS di Provinsi Jambi" didasari oleh pemikiran bahwa Koordinatorat Perguruan Tinggi Agama Islam Swasta (Kopertais) merupakan institusi yang memiliki andil yang banyak dalam rangka meningkatkan mutu pendidikan di lingkungan Perguruan Tinggi Agama Islam Swasta (PTAIS), karena pengawasan, pengendalian dan pembinaan PTAIS sesungguhnya merupakan tugas eksistensi lembaga ini. Pendekatan yang digunakan dalam penelitian ini adalah pendekatan kualitatif dengan menggunakan metode gabungan (mixed methods). Hasil analisis terhadap data kualitatif yang terkumpul melalui wawancara dan studi dokumentasi serta data kuantitatif melalui penyebaran kuesioner menyimpulkan bahwa Kopertais Wilayah XIII belum berdiri sendiri sebagai satuan kerja karena menginduk ke IAIN Sulthan Thaha Saifuddin Jambi, sehingga berdampak pada terhambatnya program kerja Kopertais yang berefek terhadap mutu PTAIS. Dengan demikian, perlu segera dilakukan restrukturisasi kelembagaan Kopertais, dengan memberikan kepastian kewenangan, penganggaran dan eselonering pengelola Kopertais.
\end{abstract}

Kata kunci: kapasitas, kopertais, mutu dan PTAIS

\begin{abstract}
The research on the capacity of Private Islamic higher Education Coordinator Region VIII in improving the quality of private Islamic higher institutions in Jambi province was based on the idea that the institution coordinator has highly contributed to improve the quality of private Islamic higher institutions because its main functions are to monitor, to control and to guide the higher institutions. The research employed qualitative approach using the mixed method. From the analysis of qualitative data collected through interviews and documentation as well as quantitative data obtained through questionnaires, it can be concluded that Private Islamic higher Education Coordinator Region VIII has not stood alone yet because it is still the under umbrella of IAIN Sulthan Taha Saifuddin Jambi. This obstacle made its programs do not run smoothly which affected the quality of private Islamic higher institutions. Thus, it is necessary to make institutional restructuring by providing certain authority, budget and echelon to administrators.
\end{abstract}

Keywords: Capacity, Private Islamic higher Education Coordinator (Kopertais), Quality and private Islamic higher institutions (PTAIS) 


\section{PENDAHULUAN}

$\mathrm{K}$ oordinatorat Perguruan Tinggi Agama Islam Swasta (Kopertais) dikukuhkan berdasarkan Keputusan Menteri Agama Nomor 74 Tahun 1982 tentang Kopertais, yang kemudian disempurnakan dengan Keputusan Menteri Agama Nomor 88 Tahun 1984 tentang Pemekaran Kopertais, Keputusan Menteri Agama Nomor 82 Tahun 1994 tentang Kopertais, Keputusan Menteri Agama Nomor 498 Tahun 1997 tentang Kopertais dan Keputusan Menteri Agama Nomor 155 Tahun 2004 tentang Kopertais, yang secara operasional ditegaskan dalam Keputusan Direktur Jenderal Pendidikan Islam, Kementerian Agama RI, Nomor Dj.I/494/2007, tentang Tugas, Fungsi dan Mekanisme Kerja Kopertais, dengan menetapkan 13 Kopertais di seluruh Indonesia.

Secara umum, keberadaan Kopertais memiliki kewajiban untuk melakukan pembinaan dalam rangka meningkatkan mutu pendidikan di Perguruan Tinggi Agama Islam Swasta (PTAIS). Secara teoritis, mutu seringkali dimaknai sebagai derajat (tingkat) keunggulan suatu produk (hasil kerja atau upaya) baik berupa barang maupun jasa, baik yang tangible maupun yang intangible. Biasanya dalam dimensi pendidikan pengertian mutu mengacu pada "proses pendidikan" dan "hasil pendidikan".

Dalam konteks "proses pendidikan" yang bermutu, di dalamnya mengandung keterlibatan faktor input, seperti bahan ajar, metodologi, sarana prasarana, dukungan administrasi dan sumberdaya lainnya serta penciptaan suasana yang kondusif. Sementara, yang dimaksud dengan mutu dalam konteks "hasil pendidikan" mengacu pada prestasi yang dicapai oleh lembaga pendidikan pada setiap kurun waktu tertentu. Prestasi yang dicapai atau hasil pendidikan (student achievement) dapat berupa hasil test kemampuan. Dalam konteks mutu pendidikan PTAIS ini, setidaknya dapat terlihat dari adanya pemenuhan Standar Nasional Pendidikan (SNP) pada penyelenggaran pendidikan di masingmasing PTAIS, yang secara administratif dapat ditunjukkan dengan perolehan nilai akreditasi pada masing-masing program studi dan institusi PTAIS.

Pendidikan Tinggi (PT), seperti halnya pendidikan dasar dan menengah merupakan tanggung jawab bersama antara pemerintah, orang tua dan masyarakat. Ini artinya, masyarakat memiliki hak untuk mendirikan dan mengelola peguruan tinggi sesuai dengan peraturan perundangundangan yang berlaku. Penyelenggaraan perguruan tinggi yang dilakukan masyarakat, dilaksanakan melalui badan yang sifatnya layanan sosial atau yayasan yang telah mendapatkan pengakuan dari pemerintah.

Di Indonesia semangat membangun perguruan tinggi sedemikian besar. Hal itu terlihat dengan jelas dari jumlah perguruan tinggi yang sedemikian banyak jumlahnya. Jika dihitung, maka tidak kurang dari 3500 perguruan tinggi di Indonesia, baik yang berstatus negeri maupun yang berstatus swasta. Perguruan Tinggi Negeri (PTN), dalam arti dikelola oleh pemerintah, jumlahnya lebih dari 130 buah. Sebagian berada di bawah pengelolaan Kementerian Pendidikan dan Kebudayaan (sekarang Kemenristekdikti), sedang 52 lagi di antaranya dikelola oleh Kementerian Agama. Dualisme pengelolaan perguruan tinggi itu tidak lepas dari sejarah kelahirannya yang justru dimulai dari perguruan tinggi yang berbasis agama, sehingga tatkala ada pikiran untuk menyatukan di antara keduanya, bukan merupakan pekerjaan mudah (http://uin-malang.ac diakses pada tanggal 4 Juni 2013).

Hal lain lagi, menyangkut Perguruan Tinggi Swasta (PTS), jumlahnya jauh lebih banyak dan menjamur baik di kota maupun kabupaten. Berdasarkan data dari rangking PTAI terdapat 625 Perguruan Tinggi Agama Islam Swasta di Indonesia terdiri atas; Fakultas Agama Islam di 93 Universitas; 26 Institut; dan 506 Sekolah Tinggi, memiliki 1089 Fakultas/Jurusan menyelenggarakan 1.407 Program studi terdiri atas; 10 Prodi pada tingkat D3; 1330 pada tingkat S1; 62 prodi tingkat S2 dan 4 Prodi pada tingkat S3.(http://www.ranking-ptai.info, diakses pada tanggal 4 Juni 2013).

Semangat mendirikan perguruan tinggi yang sedemikian besar menjadikan pertumbuhannya sedemikian cepat. Fenomena itu pada aspek tertentu memang menggembirakan, akan tetapi seringkali penambahan perguruan tinggi itu tidak memperhatikan kualitas yang sebenarnya dibutuhkan. Sehingga problem utama perguruan tinggi di Indonesia, bukan terletak pada kuantitas, 
melainkan pada kualitasnya. Oleh sebab itu, untuk menjaga kualitas pendidikan di PTAIS tersebut dimandatkan kepada 13 Kopertais.

Dengan besarnya tuntutan dan tanggung jawab yang diemban oleh Kopertais, maka eksistensi dan kapasitas Kopertais tentu saja harus "sepadan" dengan tugas dan fungsinya tersebut, karena meningkatkan mutu PTAIS yang begitu banyak juga membawa konsekuensi pada kesiapan Kopertais, baik pada aspek sumber daya manusia, pembiayaan, sarana dan prasarana serta tata kelola yang transparan dan akuntabel.

Berdasarkan hal tersebut di atas, maka diperlukan kajian yang mendalam tentang kapasitas Kopertais untuk mengetahui kemampuan kelembagaan dan kinerja yang telah dilakukan dalam rangka meningkatkan mutu pendidikan di PTAIS. Penelitian ini bertujuan untuk mendeskripsikan kapasitas Kopertais Wilayah XIII dalam meningkatkan mutu PTAIS di Provinsi Jambi. Secara praktis, penelitian ini diharapkan dapat berguna untuk menganalisis kapasitas kelembagaan Kopertais, sehingga dapat dirumuskan regulasi dan kebijakan yang sesuai dengan tuntutan tugas dan fungsi Kopertais dalam peningkatan mutu PTAIS.

\section{Tinjauan Pustaka \\ Hakikat Kapasitas}

Secara umum, kapasitas dapat dimaknai sebagai suatu tingkat keluaran, suatu kuantitas keluaran dalam periode tertentu dan merupakan kuantitas keluaran tertinggi yang mungkin selama periode waktu tersebut. Dalam Kamus Besar Bahasa Indonesia (KBBI), kapasitas berarti ruang yang tersedia, daya tampung, daya serap, keluaran maksimum kemampuan berproduksi (Pusat Bahasa, 2003: 505).

Dengan kata lain, kapasitas juga merujuk pada kecakapan dan kemampuan. McNair C.J dan Vangermeersch (1998) dalam Aditya mendefinisikan kapasitas sebagai kemampuan dari suatu organisasi atau perusahaan untuk menciptakan nilai dimana kemampuan tersebut didapatkan dari berbagai jenis sumber daya yang dimiliki oleh perusahaan. Kapasitas merupakan ukuran dari kemampuan proses produksi dalam mengubah sumber daya yang dimiliki menjadi suatu produk atau jasa yang akan digunakan oleh konsumen (Muamar Aditya: 2010).

\section{Manajemen Kelembagaan Pendidikan Tinggi}

Menurut Holt dalam Winardi, (2007: 25) "management is the process of planning, organizing, leading and controlling that encompasses human, material, financial and information resources is an organizational environment". Dengan demikian, manajemen dalam hal ini adalah proses merencanakan, mengorganisasi, melaksanakan, mengontrol sekaligus mengevaluasi kegiatan yang sedang atau telah dilaksanakan, sehingga tujuan Pendidikan Tinggi yang diinginkan sesuai dengan apa yang diharapkan.

Pendidikan Tinggi merupakan jenjang pendidikan yang dilaksanakan setelah Sekolah Menengah Atas (SMA). Istilah PT sesungguhnya masih bersifat umum, karena di dalamnya masih terdapat banyak jenjang Pendidikan Tinggi lain dengan corak dan muatan isi yang berbeda. Dilihat dari segi statusnya, PT bisa dibagi dalam dua bagian, yaitu PT yang bernaung penuh di bawah Kementerian yang berwenang (baca: Kemristekdikti dan Kemenag), PT jenis ini sering kita sebut dengan Pendidikan Tinggi Negeri (PTN), sedangkan PT yang lain adalah PT yang secara operasional dilakukan sendiri tanpa ada intervensi dari pemerintah, yang sering dikenal dengan sebutan Pendidikan Tinggi Swasta (PTS).

Undang-undang Nomor 20 Tahun 2003, menyebutkan bahwa yang dimaksud dengan "Pendidikan Tinggi" adalah kelanjutan pendidikan menengah yang mencakup program pendidikan Diploma, Sarjana, Magister, Spesialis dan Doktor yang diselenggarakan oleh perguruan tinggi.

Dalam Pendidikan Tinggi, Sumber Daya Manusia (SDM) meliputi sivitas akademika kampus baik dosen dan karyawan maupun mahasiswa. Mereka yang berkewajiban melaksanakan tugas yang ada di kampus. Oleh karenanya, diperlukan SDM yang unggul, punya komitmen terhadap perkembangan pendidikan ke depan, dan memiliki ketrampilan yang diinginkan. Menurut HAR Tilaar (1997), ada tiga sifat yang dimiliki manusia unggul, yaitu: 1) memiliki kemampuan dalam mengembangkan jaringan kerjasama (network); 2) memiliki kemampuan untuk bekerjasama dengan kelompok lain (team work); 3) berorientasi terhadap kualitas yang tinggi. 


\section{METODE PENELITIAN}

Pendekatan yang digunakan dalam penelitian ini adalah pendekatan kualitatif dengan menggunakan metode gabungan (mixed methods). Pendekatan kualitatif bertujuan untuk menggambarkan, meringkaskan berbagai kondisi, berbagai situasi atau berbagai fenomena yang terjadi, yang menjadi objek penelitian dan berupaya menarik realitas tersebut ke permukaan sebagai suatau ciri, karakter, sifat, model, tanda atau gambaran tentang kondisi, ataupun fenomena tertentu (Burhan Bungin, 2010: 68). Sedangkan metode gabungan (mixed methods) menurut Creswell (2008: 552) adalah suatu prosedur mengumpulkan data, menganalisis dan "mixing" kedua metode, kualitatif dan kuantitatif dalam suatu penelitian tunggal untuk memahami masalah penelitian.

Dalam konteks ini, pendekatan kualitatif digunakan untuk memaknai dan mendeskripsikan kondisi objektif Kopertais Wilayah XIII dalam upaya melakukan pembinaan terhadap Perguruan Tinggi Agama Islam Swasta yang didukung oleh dokumen dan informasi dari hasil wawancara (metode kualitatif) kepada pengelola Kopertais dan penyebaran kuesioner (metode kuantitatif) kepada PTAIS-PTAIS yang menjadi area kerja Kopertais Wilayah XIII.

Agar data-data yang didapatkan memadai, digunakan beberapa teknik pengumpulan data antara lain: Pertama, studi dokumentasi dilakukan untuk memperoleh data yang berasal dari dokumen-dokumen yang berkaitan dengan kebijakan Kopertais, program kerja dan kegiatan, dokumen akreditasi program studi serta dokumen yang berkenaan dengan mutu pendidikan di PTAIS. Kedua, penyebaran kuesioner yang digunakan untuk memperoleh data dari responden terkait langsung dengan penilaian PTAIS terhadap layanan Kopertais. Ketiga, wawancara mendalam (indepth interview) kepada key informan yang terlibat langsung dalam pengelolaan dan pelayanan baik Kopertais maupun PTAIS. Wawancara ini dilakukan untuk mendalami berbagai temuan dokumentatif dan hasil penyebaran kuesioner terkait dengan kapasitas Kopertais Wilayah XIII dalam meningkatkan mutu PTAIS di Provinsi Jambi.

Analisis kualitatif digunakan terhadap data kualitatif yang terkumpul melalui studi dokumentasi dan wawancara. Teknik analisis yang digunakan mencakup tiga proses analisis seperti yang dikemukakan oleh Miles dan Huberman (Norman K:1994) yaitu: reduksi data, penyajian data serta penggambaran dan pembuktian yang melibatkan peneliti dalam interpretasi terhadap data yang disajikan sehingga dapat dipahami maksudnya, kemudian ditarik kesimpulan yang bertalian dengan tujuan penelitian. Sedangkan analisis kuantitatif dilakukan terhadap data kuantitatif yang terkumpul melalui kuesioner dengan menggunakan teknik penjumlahan, nilai rerata dan prosentase. Melalui tenik ini diharapkan dapat diketahui proporsi jawaban responden terhadap tiap-tiap pertanyaan yang diajukan. Kuesioner ini menggunakan skala likert yang pada setiap pertanyaan diberikan pilihan jawaban 1-4 yang dinyatakan dalam pernyataan kualitatif sebagai berikut :

\begin{tabular}{cc}
\multicolumn{2}{c}{ Tabel 1.Skala dan Kategorisasi } \\
\hline Skala & Kategori \\
\hline $3.26-4.00$ & Sangat Baik \\
$2.51-3.25$ & Baik \\
$1.76-2.50$ & Kurang Baik \\
$1.00-1.75$ & Tidak Baik \\
\hline
\end{tabular}

\section{PEMBAHASAN}

\section{Sejarah Kopertais Wilayah XIII}

Berdasarkan Keputusan Dirjen Pendis Nomor: Dj.I/494/2007, Koordinatorat Perguruan Tinggi Agama Islam Swasta Wilayah XIII memiliki tugas membantu Direktur Jenderal Pendidikan Islam dalam pembinaan Perguruan Tinggi Agama Islam Swasta dalam bidang kelembagaan, akademik, ketenagaan, sarana dan prasarana. Dengan demikian, Kopertais merupakan "kepanjangan tangan” Dirjen Pendidikan Islam dalam konteks pengawasan, pengendalian dan pembinaan PTAIS. Namun secara struktural-faktual, posisi lembaga ini sesungguhnya menjadi tidak jelas karena keberadaannya "dititipkan" kepada IAIN Sulthan Thaha Saifuddin Jambi yang diserahterimakan dari Kopertais Wilayah VI IAIN Imam Bonjol Padang, Provinsi Sumatera Barat dan Kopertais Wilayah VII IAIN Raden Fatah Palembang, Provinsi Sumatera Selatan pada tanggal 11 April 2008.

Dengan status kelembagaan yang "dititipkan" ini, pada akhirnya memposisikan Kopertais Wilayah XIII tidak memiliki kepastian penganggaran untuk pelaksanaan program dan operasional lembaga 
serta para pengelolanya tidak memiliki ketetapan eselon (job grading). Meskipun demikian, di tengah ketidakjelasan status kelembagaan Kopertais Wilayah XIII tetap harus menjalankan tugas dan fungsi lembaga sesuai dengan amanat Keputusan Dirjen Pendis. Berdasarkan buku pedoman akademik (2012), jumlah binaan Kopertais Wilayah XIII sebanyak 15 PTAIS, dengan komposisi kelembagaan; 9 Sekolah Tinggi Agama Islam (STAI) dan 6 Sekalah Tinggi Ilmu Tarbiyah (STIT) dengan jumlah program studi 29 yang tersebar di wilayah Provinsi Jambi.

Menjadikan Kopertais Wilayah XIII IAIN Sulthan Thaha Saifuddin Jambi sebagai lembaga pengawas, pengendali mutu dan pembina Perguruan Tinggi Agama Islam Swasta yang maju dan berkeunggulan, merupakan visi dari Kopertais Wilayah XIII. Adapun misinya, mengawas, mengendali mutu dan membina Perguruan Tinggi Agama Islam Swasta yang berada dalam lingkungan Kopertais Wilayah XIII IAIN Sulthan Thaha Saifuddin Jambi agar dapat mencapai tujuan.

Atas dasar visi misi tersebut Kopertais Wiyah XIII melakukan beberapa penguatan : Pertama, Kopertais memperkuat diri sebagai pusat data keberadaan PTAIS. Data merupakan aspek yang sangat penting, karena data jumlah PTAIS yang ada, sering disampaikan berbeda-beda. Kopertais berperan dalam memvalidasinya. Kedua, Kopertais sebagai lembaga penjaminan mutu PTAIS, antara lain terkait dengan masalah akreditasi. Dengan kondisi demikian, tugas Kopertais menjadi makin berat, apalagi target pemerintah, semua program studi harus sudah terakreditasi pada tahun 2015. Ketiga, Kopertais sebagai mitra kerja Kementerian Agama, meskipun dalam status menjadi perpanjangan tangan Kementerian Agama, namun berbagai kebijakan yang ada saat ini belum mencerminkan hal itu (Hadri Hasan, wawancara, 6/7/2013).

Sebagai wujud dari penguatan tersebut, Kopertais Wilayah XIII merencanakan dan melaksanaan program kerja yang secara umum dikelompokkan ke dalam 3 bagian yaitu : Pertama, pengawasan PTAIS dalam bentuk validasi laporan administrasi kelembagaan, ketenagaan dan mahasiswa dengan cara visitasi, monitoring proses dan evaluasi berkala serta pelaporan kepada
Ditjen Pendis. Kedua, pengendalian mutu dan out put dalam bentuk administrasi, registrasi dan visitasi, rekomendasi perijinan program studi serta rekomendasi bantuan sarana. Ketiga, pembinaan kelembagaan, ketenagaan dan administrasi akademik dan kemahasiswaan berupa sosialisasi, workshop, pelatihan fasilitasi rapat koordinasi dan pemberian reward dan fanisment secara adil

Dalam menjalankan program tersebut Kopertais Wilayah XIII dipimpin langsung oleh Dr. H. Hadri Hasan, Rektor IAIN Sulthan Thaha Saifuddin Jambi berdasarkam Keputusan Dirjen Pendis Nomor: Dj.I/ 494/2007, yang menetapkan Jabatan Koordinator adalah ex officio Rektor IAIN/ UIN. Selanjutnya Kordinator dalam melaksanakan tugasnya berdasarkan kewenangannya yang diamanatkan SK Dirjen tersebut mengangkat 2 orang Wakil Kordinator yang menangani bidang pembelajaran dan akademik serta bidang manajemen SDM dan lembaga. Selain itu, ada pembina akademik, sekretaris dan wakil, kabag bina PTAIS, kasubag AUAK, bendahara dan wakil, serta ditambah lima staf administrasi yang mengurusi bidang pekerjaan masing-masing, sehinggal total SDM Kopertais Wilayah XIII adalah 15 orang. Semua yang diangkat adalah pejabat atau dosen dari unsur lingkungan IAIN Sulthan Thaha Saifuddin Jambi.

Struktur Kopertais seperti diatas kurang seirama dengan maksud Keputusan Dirjen Pendis Nomor: Dj.I/ 494/2007 dimana poin keenam menetapkan bahwa Wakil Koordinator diangkat dari unsur Perguruan Tinggi Agama Islam Swasta (PTAIS) yang memiliki reputasi dan performance yang baik di lingkungan masing-masing wilayah. Padahal penetapan dan penerapan pedoman kode etik pegawai mengacu pada sikap dan perilaku dalam memberikan pelayanan kepada pengguna layanan (PTAIS), begitu juga dengan kedisiplinan pegawai dalam memberikan pelayanan kepada pengguna layanan dan kepekaan atau respon pegawai dalam memberikan pelayanan kepada pengguna layanan dan keterampilan pegawai dalam memberikan pelayanan kepada pengguna layanan mengacu pada Peraturan Dirjen Pendis tersebut.

Dengan demikian, kebijakan pengembangan pegawai dalam rangka peningkatan keterampilan dan profesionalisme pegawai dengan tujuan 
meningkatkan kualitas pelayanan kepada pengguna pelayanan menuntut adanya kebijaksanaan khusus terkait penambahan pegawai, terutama pegawai yang bertugas khusus dalam memberikan pelayanan dan pengolahan website, sehingga data dapat di $u p$ date setiap waktu.

Sebagai sebuah lembaga yang berfungsi untuk melakukan pengawasan, pengendalian dan pembinaan terhadap mutu PTAIS, Kopertais Wilayah XIII pada tahun 2013 memperoleh dana operasional sebesar Rp. 315.000 .000 yang menginduk pada DIPA IAIN Sulthan Thaha Saifuddin Jambi. Berdasarkan dari data dokumentasi terkait anggaran Kopertais Wilayah XIII mengalami penurunan dari anggaran sebelumnya, sementara beban yang di tanggung semakin bertambah. Oleh sebab itu, minimnya anggaran tersebut berkorelasi dengan tugas pokok dan fungsi Kopertais terhadap PTAIS menjadi kurang maksimal. Selengkapnya bisa dilihat dalam tabel berikut:

Tabel 2. Anggaran Pembiayaan Kopertais Wilayah XIII Tiga Tahun Terakhir

\begin{tabular}{clccc}
\hline No & \multicolumn{1}{c}{ Mata Anggaran } & $\mathbf{2 0 1 1}$ & $\mathbf{2 0 1 2}$ & $\mathbf{2 0 1 3}$ \\
\hline 1 & Honor yang terkait dengan Satuan Kerja & 96.150 .000 & 117.600 .000 & 98.400 .000 \\
2 & Belanja Bahan & 100.000 .000 & 16.000 .000 & 29.400 .000 \\
3 & Belanja Non Operasional & 238.850 .000 & 26.000 .000 & 15.000 .000 \\
4 & Belanja Perjalanan Biasa & 65.000 .000 & 78.800 .000 & 60.000 .000 \\
5 & Honor Output Kegiatan & - & 53.100 .000 & 68.300 .000 \\
6 & Belanja Bahan Rakorwil & - & 38.000 .000 & 33.800 .000 \\
7 & Honor Output Rakorwil & - & 7.500 .000 & 10.100 .000 \\
8 & Belanja perjalanan Rakorwil & - & 13.000 .000 & - \\
\hline & $\quad$ Jumlah & 500.000 .000 & 350.000 .000 & 315.000 .000 \\
\hline
\end{tabular}

Sumber : Bendahara (2013)

Jumlah anggaran pertahun dirasakan sangat tidak memadai untuk melakukan tugas dan fungsi pengawasan, pengendalian dan pembinaan PTAIS, terlebiih untuk penyediaan sarana dan prasarana yang memadai. Sehingga sampai saat ini Kopertais Wilayah XIII sekretariatnya masih menumpang pada IAIN Sultan Thaha Saifudin. Ini berakibat saling tarik kepentingan antara pihak Rektorat dan pihak Kopertais. Semua sarana dan prasarana yang ada masih hak mutlak IAIN Sultan Thaha Saifudin.

Hal itu diungkapkan oleh Kabag Bina PTAIS yang mengatakan bahwa; "...kondisi anggaran yang ada belum sebanding dengan keberadaan PTAIS, karena meskipun secara jumlah tidak begitu banyak namun jarak PTAIS yang satu dengan yang lainnya sangat berjauhan dan memakan waktu dan biaya transportasi yang sangat mahal, terlebih ketidakadaan sarana akomodasi seperti mobil atau motor dinas. Padahal idealnya Kopertais memiliki bangunan sendiri, sehingga punya kantor sendiri dan memiliki sarana prasarana yang memadai, seperti aula untuk rapat dan pertemuan, ruangan untuk pelatihan dan mess atau penginapan untuk para tamu, mengingat jarak PTAIS dengan Kopertais berjauhan. Namun harapan tersebut selalu terkendala dengan dana, apalagi sistem anggaran yang terpusat dan pengadaan bersifat sentralistik dari biro, rentan terjadi salah paham antara kebutuhan yang penting dan mendesak dengan yang kurang penting, terlebih ketika anggaran Kopertais tiap tahun mengalami penurunan. Maka solusi yang paling tepat adalah dengan menjadikan Kopertais sebagai satuan kerja sendiri, sehingga bisa mandiri (Nawawi, 6/7/2013).

Menyadari keterbatasan dana yang tersedia, maka setiap ada kegiatan yang berkaitan teknis pengawasan, pengendalian mutu dan pembinaan Perguruan Tinggi Agama Islam Swasta dalam bidang kelembagaan dan akademik, selalu dimintakan partisipasi biaya dari PTAIS yang bersangkutan. Sistem pembiayaan seperti ini sudah seharusnya direformasi karena pertanggungjawaban dan akuntabilitas serta keterbukaan pembiayaannya tidak senafas dengan semangat reformasi dan dirasakan cukup memberatkan PTAIS, sudah selayaknya semua pembiayaan tersebut dibebankan pada Anggaran Pendapatan dan Belanja Negara $(\mathrm{APBN})$. 


\section{Mutu PTAIS}

Berdasarkan deskripsi di atas, maka dapat dikatakan bahwa sesungguhnya kapasitas Kopertais Wilayah XIII masih jauh dari kondisi ideal. Selain persoalan status kelembagaan yang tidak jelas, karena masih menginduk kepada IAIN Sultan Thaha Saifudin, juga minimnya dukungan SDM, dana yang tidak memadai serta sarana prasarana yang tidak dimiliki. Di lain sisi, Kopertais Wilayah XIII memiliki tugas, fungsi dan tanggung jawab untuk menjaga dan mengontrol mutu PTAIS.

Mutu PTAIS yang dimaksud dalam penelitian ini hanya terbatas pada mutu PTAIS berdasarkan hasil akreditasi yang dilakukan oleh Badan Akreditasi Nasional Perguruan Tinggi (BAN-PT). Badan Akreditasi Nasional Perguruan Tinggi berdiri pada tahun 1994, berlandaskan UU No. 2 tahun 1989 tentang Sistem Pendidikan Nasional dan PP Nomor 60 tahun 1999 tentang Pendidikan Tinggi. Sebagai satu satunya badan akreditasi yang diakui oleh pemerintah BAN-PT memiliki wewenang untuk melaksanakan sistem akreditasi pada Pendidikan Tinggi, karena merupakan badan yang mandiri (independen) yang diangkat pemerintah. Fungsi utama BAN-PT pada dasarnya adalah membantu Menteri Pendidikan dalam pelaksanaan salah satu kewajiban perundangannya, yaitu penilaian mutu perguruan tinggi yang meliputi Perguruan Tinggi Negeri (PTN), Perguruan Tinggi Swasta (PTS), Perguruan Tinggi Agama (PTA) dan Perguruan Tinggi Kedinasan (PTK).

Berdasarkan fungsi dan posisi BAN-PT tersebut, mutu PTAIS di Provinsi Jambi yang diindikasikan dengan perolehan nilai akreditasi program studi menunjukan hasil yang lumayan baik, maka kinerja Kopertais Wilayah XIII ini patut diapresiasi, meskipun belum ada satupun Program Studi yang mendapat nilai akreditasi A, namun demikian dari 29 Program Studi yang dibina, 17\% Program Studi sudah memperoleh nilai akreditasi B, 38\% Program Studi memperoleh akreditasi C, dan ada $45 \%$ Program Studi yang belum terakreditasi. Selengkapnya dapat dilihat pada tabel di bawah ini:
Tabel 3. Perolehan Akreditasi Program Studi Di Wilayah Kerja Kopertais Wilayah XIII Provinsi Jambi

\begin{tabular}{|c|c|c|c|c|c|c|}
\hline \multirow[t]{2}{*}{ No } & \multirow[t]{2}{*}{ Nama Prodi } & \multicolumn{5}{|c|}{ Status Akreditasi } \\
\hline & & A & B & $\mathrm{C}$ & BT & Total \\
\hline 1 & $\begin{array}{l}\text { Pendidikan Agama } \\
\text { Islam }\end{array}$ & & 4 & 6 & 1 & 11 \\
\hline 2 & Kependidikan Islam & & 1 & & & 1 \\
\hline 3 & $\begin{array}{l}\text { Komunikasi dan } \\
\text { Penyiaran Islam }\end{array}$ & & & 1 & & 1 \\
\hline 4 & Ekonomi Syariah & & & & 6 & 6 \\
\hline 5 & $\begin{array}{l}\text { Hukum dan Ekono- } \\
\text { mi Syariah }\end{array}$ & & & 1 & & 1 \\
\hline 6 & $\begin{array}{l}\text { Akhwas Al-Syakh- } \\
\text { siah }\end{array}$ & & & 2 & & 2 \\
\hline 7 & $\begin{array}{l}\text { Manajemen Pendidi- } \\
\text { kan Islam }\end{array}$ & & & 1 & 3 & 4 \\
\hline 8 & $\begin{array}{l}\text { Pendidikan Bahasa } \\
\text { Arab }\end{array}$ & & & & 2 & 2 \\
\hline 9 & Pendidikan Guru MI & & & & 1 & 1 \\
\hline Jum & lah & & 5 & 11 & 13 & 29 \\
\hline
\end{tabular}

Status akreditasi sesungguhnya hanya merupakan salah satu indikator penilaian terhadap penyelenggaraan perguruan tinggi, namun sepertinya telah dijadikan "segala-galanya" oleh pengelola perguruan tinggi khususnya PTAIS. Salah kaprah pemahaman masyarakat termasuk dunia usaha dan kalangan pemerintahan terhadap akreditasi juga turut mendukung terlalu dipentingkannya akreditasi oleh kalangan perguruan tinggi sehingga banyak mengabaikan indikator lainnya.

Akreditasi telah dianggap sebagai legalitas sebuah program studi atau lembaga pendidikan tinggi bahkan dianggap sebagai jaminan terhadap mutu lulusannya, padahal sesungguhnya legalitas untuk sebuah perguruan tinggi bukanlah akreditasi tetapi berupa izin operasional dari pemerintah melalui Direktorat Jenderal Pendidikan Islam yang perpanjangan tangannya di daerah adalah Kopertais. Izin operasional ini secara periodik mesti diperbaharui dimana salah satu pertimbangan perpanjangan izin tersebut adalah pengisian laporan Evaluasi Program Studi Berbasis Evaluasi Diri (EPS-BED) yang diganti dengan Pangkalan Data Pergurun Tinggi (PDPT).

Oleh sebab itu, penentuan penerimaan lulusan perguruan tinggi bagi para penggunanya mestinya lebih ditekankan pada kompetensi, kapasitas 
kemampuan, dan kualitas individu lulusan yang bersangkutan yang ditentukan berdasarkan seleksi yang dilakukan. Jadi sangat tidak logis jika kualitas lulusan ditentukan oleh kategori akreditasi program studinya tetapi ditentukan oleh kualitas individu yang bersangkutan, sehingga diharapkan dunia usaha dan dunia industri tidak lagi mensyaratkan kategori hasil akreditasi lembaga pendidikan tinggi sebagai penentu diterima atau tidak seseorang mengisi lowongan pekerjaan yang ada (Mawardi Sadim, wawancara, 10/7/2015).

Terlepas dari salah kaprah tentang pemahaman akreditasi tersebut, hal lain yang terkait dengan akreditasi adalah lamanya waktu yang dibutuhkan sampai keluar hasilnya. Hal tersebut, disebabkan oleh terbatasnya tenaga asesor, luasnya wilayah yang digarap, serta banyaknya program studi yang jumlahnya terus bertambah, padahal mulai 2012 setiap program studi sudah wajib terakreditasi.

Hal itu menjadi kekhawatiran bagi kalangan PTAIS yang selama ini sangat membutuhkan status akreditasi tersebut sebagai modal promosi dan selalu dijadikan sebagai "objek pengawasan secara ketat", tidak seperti PTN yang kelihatannya "tenangtenang saja" dengan akreditasi ini. Wacana untuk "mendesentralisasi" akreditasi dengan catatan tetap di bawah koordinasi BAN-PT pusat rasanya menjadi salah satu alternatif dalam upaya mempercepat proses akreditasi tersebut (M. Saman, wawancara, 8/7/2015).

Persoalan PTAIS lainnya adalah persoalan yang saling terkait antara rendahnya atmosfir akademik, persoalan kuantitas dan kualitas tenaga akademik termasuk jenjang jabatan dan gelar akademiknya, ketersediaan fasilitas pendukung dan mutu pembelajaran. Rendahnya atmosfir akademik terkait dengan kualitas tenaga pengajar yang masih sebagian besar bergelar S-1 dan rendahnya jumlah dosen yang jabatan akademiknya lektor ke atas.

Rendahnya dosen yang memiliki gelar S-2 dan S-3 terkait dengan kurangnya program perguruan tinggi untuk menyekolahkan dosennya karena berkaitan alokasi dana PTAIS. Tidak adanya alokasi dana ini terkait dengan lemahnya keuangan PTAIS karena rendahnya rata-rata jumlah mahasiswa per program studi, disamping kurangnya perhatian pimpinan PTAIS dan yayasan untuk memprogramkan pendidikan lanjutan bagi dosennya (Maryadi Syarif, wawancara, 15/7/2015).

Rendahnya atmosfir akademik terkait pula dengan rendahnya fasilitas penunjang seperti perpustakaan dan laboratorium yang biasanya di banyak PTAIS hanya untuk sekedar memenuhi persyaratan formal, bukan untuk memenuhi kebutuhan dosen dan mahasiswa dalam aktifitas akademik mereka, bahkan ada PTAIS yang memajang buku dan menata laboratorium hanya saat akan ada visitasi asesor ataupun adanya kunjungan pihak berwenang dalam penentu kebijakan di bidang pendidikan.

Rendahnya aktifitas akademik juga terkait dengan kurangnya program yang terencana dari pimpinan PTAIS dan kurangnya dukungan yayasan untuk melakukan kegiatan ilmiah yang terprogram dan berkelanjutan seperti diskusi ilmiah, seminar hasil penelitian, bedah buku, dan lain-lain. Kalaupun ada kegiatan ilmiah, sebagian besar hanya ditujukan untuk tujuan promosi yang lebih ditekankan pada seremoninya daripada substansi keilmiahannya. (Musthafa, wawancara, 13/7/2015).

Kurangnya sarana pendukung kegiatan akademik, kualitas tenaga dosen, atmosfir akademik yang lemah serta kurangnya dana pendukung menjadi saling terkait yang mengakibatkan belum meningkatnya mutu pendidikan di sebagian besar PTAIS, ditambah lagi kualitas bahan baku mahasiswa yang rendah karena diperoleh tanpa melalui proses seleksi yang memadai bahkan lebih sering tanpa proses seleksi sama sekali, sehingga salah satu langkah yang bisa dilakukan oleh pemerintah adalah dengan meningkatkan peran Kopertais dalam hal pengawasan, pengendalian dan pembinaannya terhadap PTAIS termasuk membantu dalam fasilitas, pengembangan sumberdaya manusia dan peningkatan kelembagaan serta manajemen mutu PTAIS.

Kopertais perlu ditingkatkan kapasitas dan kewenangannya yang selama ini telah banyak berkurang. Untuk itu reorganisasi Kopertais perlu dilakukan dengan memperbesar organisasinya dan melengkapi pejabat yang ada di dalamnya dengan pejabat yang berlatar belakang penguasaan akademis seperti model Kopertis yang berada dibawah Kementerian Pendidikan, sehingga tidak hanya diisi oleh pejabat dengan kemampuan administratif saja karena yang dilayani adalah dunia perguruan tinggi.

Upaya lainnya yang dapat dilakukan adalah peningkatan kerjasama antar PTAIS baik secara sendiri-sendiri maupun secara kolektif melalui organisasinya seperti Asosiasi Perguruan Tinggi Swasta Indonesia (APTISI). Kerjasama dimaksud tentu terkait dengan penguatan posisi tawar ketika berhadapan dengan berbagai pihak, pembangunan 
kapasitas, maupun penguatan kelembagaan PTAIS secara keseluruhan.

\section{Tanggapan PTAIS Terhadap Pelayanan Kopertais Wilayah XIII}

Kopertais merupakan salah satu lembaga yang bergerak dalam bidang pelayanan publik. Dalam konteks ke-Indonesia-an, penggunaan istilah pelayanan publik (public service) dianggap memiliki kesamaan arti dengan istilah pelayanan umum atau pelayanan masyarakat. Oleh karenanya ketiga istilah tersebut dipergunakan secara interchangeable dan dianggap tidak memiliki perbedaan mendasar.

Dalam Kamus Besar Bahasa Indonesia dinyatakan bahwa pelayanan adalah perihal atau cara melayani; usaha melayani kebutuhan orang lain dengan memperoleh imbalan; atau kemudahan yang diberikan sehubungan dengan jual beli barang atau jasa (http://kbbi.web.id, diakses pada tanggal 4 Juni 2013). Sementara istilah publik berasal dari bahasa Inggris (public), yang memiliki variasi arti dalam bahasa Indonesia, yaitu umum, masyarakat dan negara (Purwadarminta, 1976 : 771).

Publik dalam pengertian umum atau masyarakat dapat kita temukan dalam istilah public offering (penawaran umum), public ownership (milik umum), dan public utility (perusahaan umum), public relations (hubungan masyarakat), public service (pelayanan masyarakat), public interest (kepentingan umum). Sedangkan dalam pengertian negara salah satunya adalah public authorities (otoritas negara), public building (bangunan negara), public revenue (penerimaan negara) dan public sector (sektor negara). Dalam hal ini, pelayanan publik merujukkan istilah publik lebih dekat pada pengertian masyarakat atau umum, meskipun pengertian publik yang melekat pada pelayanan publik tidak sepenuhnya sama dan sebangun dengan pengertian masyarakat.

Keputusan Menteri Negara Pendayagunaan Aparatur Negara (Meneg PAN) Nomor 63/ KEP/M.PAN/7/2003, memberikan pengertian pelayanan publik yaitu segala kegiatan pelayanan yang dilaksanakan oleh penyelenggara pelayanan publik sebagai upaya pemenuhan kebutuhan penerima pelayanan maupun pelaksanaan ketentuan peraturan perundang-undangan.

Pelayanan publik identik dengan representasi dari eksistensi birokrasi pemerintahan, karena berkenaan langsung dengan salah satu fungsi pemerintah yaitu memberikan pelayanan. Oleh karenanya sebuah kualitas pelayanan publik merupakan cerminan dari sebuah kualitas birokrasi pemerintah. Di masa lalu, paradigma pelayanan publik lebih memberi peran yang sangat besar kepada pemerintah sebagai sole provider. Peran pihak di luar pemerintah tidak pernah mendapat tempat atau termarjinalkan. Masyarakat dan dunia swasta hanya memiliki sedikit peran dalam penyelenggaraan pelayanan publik. Fungsi pelayanan publik adalah salah satu fungsi fundamental yang harus diemban pemerintah baik di tingkat pusat maupun di daerah. Fungsi ini juga diemban dalam memberikan dan menyediakan layanan jasa dan atau barang publik

Dalam konsep pelayanan, dikenal dua jenis pelaku pelayanan, yaitu penyedia layanan dan penerima layanan. Penyedia layanan atau service provider (Barata, 2003: 11) adalah pihak yang dapat memberikan suatu layanan tertentu kepada konsumen, baik berupa layanan dalam bentuk penyediaan dan penyerahan barang (goods) atau jasa-jasa (services). Penerima layanan atau service receiver adalah pelanggan (customer) atau konsumen (consumer) yang menerima layanan dari para penyedia layanan.

Berdasarkan hasil sebaran kuesioner terkait penilaian user (PTAIS) terhadap layanan (kinerja) Kopertais dengan menggunakan 3 variable utama, yaitu transparansi, kredibilitas dan kepuasan, ditemukan keselarasan antara mutu PTAIS dengan penilaian PTAIS terhadap kinerja Kopertais Wilayah XIII.

\section{Transparansi}

Transparansi adalah prinsip yang menjamain akses atau kebebasan bagi setiap orang untuk memperoleh informasi tentang penyelenggaraan pemerintahan, yaitu informasi tentang kebijakan proses pembuatan dan pelaksanaanya serta hasilhasil yang dicapai (Bappenas : 2002). Sementara menurut Meutia Rahman (2000) transparansi adalah adanya kebijakan terbuka bagi pengawasan informasi mengenai setiap aspek kebijakan pemerintah yang dapat dijangkau publik. Keterbukaan informasi diharapkan akan menghasilkan persaingan politik yang sehat, toleran dan kebijakan dibuat beradasarkan preferensi publik.

Adapun menurut Mardiasmo (2004), transparansi berarti keterbukaan (opennsess) pemerintah dalam memberikan informasi yang terkait dengan aktivitas pengelolaan sumber daya publik kepada pihak-pihak yang membutuhkan 
informasi. Pemerintah berkewajiban memberikan informasi keuangan dan informasi lainya yang akan digunakan untuk pengambilan keputusan oleh pihak - pihak yang berkepentingan.

Dengan adanya transparansi yang baik pada akhirnya akan menciptakan horizontal accountability antara Kopertais dengan PTAIS sehingga tercipta suasana kerja yang bersih, efektif, efisien, akuntabel dan responsif terhadap aspirasi dan kepentingan lembaga. Berikut respon PTAIS terhadap Kopertais terkait aspek transparansi :

Tabel 4. Aspek Transparansi Perspektif PTAIS

\begin{tabular}{llll}
\hline No & Aspek Transparansi & Skor & Kategori \\
\hline Pembinaan & 2.83 & Baik \\
1 & Peningkatan wawasan dari hasil pembinaan Kopertais & 2.93 & Baik \\
2 & Kepercayaan yang tinggi terhadap pembinaan Kopertais & 3.07 & Baik \\
3 & Kemudahan mengakses informasi terkait pembinaan Kopertais & 2.87 & Baik \\
4 & Kelengkapan informasi terkait dengan pembinaan Kopertais & 2.47 & Kurang Baik \\
Pengawasan & 2.77 & Baik \\
5 & Peningkatan wawasan dari hasil pengawasan Kopertais & 2.67 & Baik \\
6 & Kepercayaan yang tinggi terhadap pengawasan Kopertais & 3.07 & Baik \\
7 & Kemudahan mengakses informasi terkait pengawasan Kopertais & 2.73 & Baik \\
8 & Kelengkapan informasi terkait pengawasan oleh Kopertais & 2.60 & Baik \\
Pengendalian & 2.75 & Baik \\
9 & Peningkatan wawasan dari hasil pengendalian mutu Kopertais & 2.67 & Baik \\
10 & Kepercayaan yang tinggi terhadap pengendalian mutu Kopertais & 2.93 & Baik \\
11 & Kemudahan mengakses informasi terkait pengendalian mutu Kopertais & 2.80 & Baik \\
12 & Kelengkapan informasi terkait pengendalian mutu Kopertais & 2.60 & Baik \\
\hline Skor Rata-Rata & 2.78 & Baik \\
\hline
\end{tabular}

Sumber data: kuesioner yang diolah

Berdasarkan data diatas transparansi Kopertais Wilayah XIII persfektif PTAIS rata-rata ada dalam kategori baik, kecuali pada poin kelengkapan informasi terkait dengan pembinaan Kopertais masih dalam kategori kurang baik, sehingga perlu diadakan perbaikan sarana dan prasarana terutama media komunikasi untuk mempermudah pengaduan seperti website.

Transparansi berarti terbukanya akses bagi semua pihak yang berkepentingan terhadap setiap informasi, sehingga transparansi dibangun atas pijakan kebebasan arus informasi yang memadai disediakan untuk dipahami dan (untuk kemudian) dapat dipantau. Transparansi jelas mengurangi tingkat ketidakpastian dalam proses pengambilan keputusan dan implementasi kebijakan publik.
Sebab, penyebarluasan berbagai informasi yang selama ini aksesnya hanya dimiliki Kopertais dapat memberikan kesempatan kepada berbagai komponen PTAIS untuk turut mengambil keputusan.

\section{Kredibilitas}

Menurut Rakhmat (2004:257) bahwa kredibilitas adalah seperangkat persepsi komunikasi tentang sifat-sifat komunikator, sedangkan Susanto (2004:15) berpendapat bahwa kredibilitas ialah dugaan orang akan tidak atau kurang adanya kepentingan akan hal yang disebut sepintas lalu, membuat orang lebih yakin akan kesungguhan dan kemurniaan pernyataannya. Berikut respon PTAIS terhadap Kopertais terkait kredibilitas: 
Tabel 5. Aspek Kredibilitas Perspektif PTAIS

No

Pembinaan

1 Pembinaan mutu oleh Kopertais, sudah menjawab kebutuhan PTAIS

2 Kemudahan menerapkan hasil pembinaan oleh Kopertais

3 Hasil pembinaan Kopertais sesuai dengan pencapaian visi dan misi PTAIS

4 Hasil pembinaan mutu oleh Kopertias digunakan sebagai referensi utama dalam merumuskan kebijakan di PTAIS

Pengawasan

5 Pengawasan mutu oleh Kopertais, sudah menjawab kebutuhan PTAIS

6 Kemudahan menerapkan hasil pengawasan oleh Kopertais di PTAIS

7 Hasil pengawasan oleh Kopertais sesuai dengan pencapaian visi dan misi PTAIS

8 Hasil pengawasan mutu oleh Kopertias digunakan sebagai referensi utama dalam merumuskan kebijakan di PTAIS

Pengendalian

9 Pengendalian mutu oleh Kopertais, sudah menjawab kebutuhan PTAIS

10 Kemudahan menerapkan hasil pengendalian oleh Kopertais di PTAIS

11 Hasil pengendalian oleh Kopertais sesuai dengan pencapaian visi dan misi PTAIS

12 Hasil pengendalian mutu oleh Kopertais digunakan sebagai referensi utama dalam merumuskan kebijakan di PTAIS

Skor Rata-Rata

Sumber data: kuesioner yang diolah

$\begin{array}{cc}\text { Skor } & \text { Kategori } \\ 2.62 & \text { Baik } \\ 2.47 & \begin{array}{c}\text { Kurang } \\ \text { Baik }\end{array} \\ 2.47 & \begin{array}{c}\text { Kurang } \\ \text { Baik }\end{array} \\ 2.80 & \text { Baik } \\ 2.73 & \text { Baik } \\ 2.63 & \text { Baik } \\ 2.67 & \text { Baik } \\ 2.60 & \text { Baik } \\ 2.60 & \text { Baik } \\ 2.67 & \text { Baik } \\ 2.73 & \text { Baik } \\ 2.73 & \text { Baik } \\ 2.93 & \text { Baik } \\ 2.60 & \text { Baik } \\ 2.67 & \text { Baik } \\ 2.66 & \text { Baik }\end{array}$

Aspek pembinaan mutu oleh Kopertais dalam menjawab kebutuhan PTAIS dan kemudahan menerapkan hasil pembinaan oleh Kopertais ada dalam posisi kurang baik. Salah satu indikator ketidakberdayan Kopertais dalam hal ini adalah sarana prasarana yang tidak memadai, sementara jarak antara Kopertis dengan PTAIS berjauhan, di samping itu faktor SDM yang rangkap jabatan mempengaruhi konsentrasi dalam menjalankan tugas pokok dan fungsi Kopertais.

\section{Kepuasan}

Kata kepuasan atau satisfaction berasal dari bahasa latin "satis" yang artinya cukup baik atau memadai, dan "facia" artinya melakukan atau membuat, sehingga sederhana dapat diartikan upaya pemenuhan sesuatu (Azwar, 2000:32). Sementara Robins (dalam Hardjana, 2000:139) mengemukakan kepuasan bisa dikaitkan dengan menghitung selisih antara apa yang dirasakan, diinginkan dan didapatkan. Berikut respon PTAIS terhadap Kopertais terkait kepuasan layanan:
Tabel 6. Aspek Kepuasan Perspektif PTAIS

\begin{tabular}{|c|c|c|c|}
\hline No & Kepuasan Pelayanan & Skor & Kategori \\
\hline 1 & $\begin{array}{l}\text { Pedoman Pembinaan } \\
\text { PTAIS }\end{array}$ & 3.07 & Baik \\
\hline 2 & $\begin{array}{l}\text { Pedoman Pengawasan } \\
\text { PTAIS }\end{array}$ & 2.87 & Baik \\
\hline 3 & $\begin{array}{l}\text { Pedoman Pengendalian } \\
\text { PTAIS }\end{array}$ & 2.80 & Baik \\
\hline 4 & $\begin{array}{l}\text { Kejelasan prosedur } \\
\text { pelayanan }\end{array}$ & 3.00 & Baik \\
\hline 5 & $\begin{array}{l}\text { Kejelasan pegawai yang } \\
\text { melayani }\end{array}$ & 3.13 & Baik \\
\hline 6 & $\begin{array}{l}\text { Kejelasan unit kerja yang } \\
\text { melayani }\end{array}$ & 3.07 & Baik \\
\hline 7 & $\begin{array}{l}\text { Profesionalisme } \\
\text { pembinaan }\end{array}$ & 2.73 & Baik \\
\hline 8 & $\begin{array}{l}\text { Profesionalisme } \\
\text { pengawasan }\end{array}$ & 3.07 & Baik \\
\hline 9 & $\begin{array}{l}\text { Profesionalisme } \\
\text { pengendalian }\end{array}$ & 2.80 & Baik \\
\hline 10 & $\begin{array}{l}\text { Profesionalisme } \\
\text { pengembangan mutu }\end{array}$ & 2.87 & Baik \\
\hline 11 & $\begin{array}{l}\text { Cepat memberikan } \\
\text { pelayanan }\end{array}$ & 3.07 & Baik \\
\hline 12 & $\begin{array}{l}\text { Memahami masalah } \\
\text { PTAIS }\end{array}$ & 2.67 & Baik \\
\hline 13 & $\begin{array}{l}\text { Cepat menyelesaikan } \\
\text { masalah }\end{array}$ & 3.00 & Baik \\
\hline
\end{tabular}




\begin{tabular}{|c|c|c|c|}
\hline 14 & $\begin{array}{l}\text { Memahami kebutuhan } \\
\text { PTAIS }\end{array}$ & 2.67 & Baik \\
\hline 15 & $\begin{array}{l}\text { Kunjungan dalam } \\
\text { pembinaan PTAIS }\end{array}$ & 3.13 & Baik \\
\hline 16 & $\begin{array}{l}\text { Pegawai ramah dalam } \\
\text { melayani }\end{array}$ & 3.53 & $\begin{array}{l}\text { Sangat } \\
\text { Baik }\end{array}$ \\
\hline 17 & $\begin{array}{l}\text { Pegawai Bersahabat dalam } \\
\text { melayani }\end{array}$ & 3.53 & $\begin{array}{l}\text { Sangat } \\
\text { Baik }\end{array}$ \\
\hline 18 & $\begin{array}{l}\text { Pegawai sabar dalam } \\
\text { melayani }\end{array}$ & 3.20 & Baik \\
\hline Skor & ata-Rata & 3.01 & Baik \\
\hline
\end{tabular}

Terkait kepuasan hampir semua aspek ada dalam kategori baik, terlebih aspek bersahabat dan ramah dalam pelayanan ada dalam kategori sangat baik. Ini menunjukan harmonisasi antara Kopertais dan PTAIS telah terjalin dengan baik dan perlu dipertahankan. Untuk poin pedoman pengawasan, pengendalian, profesionalisme pembinaan, pengendalian dan pengembangn mutu, memahami masalah dan kebutuhan PTAIS meskipun sudah ada dalam kategori baik, namun masih perlu ditingkatkan.

Dari ketiga variable data di atas dapat diketahui, pelayanan Kopertais Wilayah XIII dalam meningkatkan mutu PTAIS berdasarkan persepektif PTAIS di Provinsi Jambi berada dalam kategori baik meskipun dalam kondisi tenaga, fasilitas dan sarana prasarana serba terbatas. Hal itu bisa terlihat melalui nilai rerata respon dari 15 PTAIS : 2.78 untuk transparansi dan 2,66 untuk kredibilitas serta 3.01 untuk kepuasan. Selengkapnya dapat dilihat pada grafik di bawah ini.

\section{Grafik : 1}

Respon PTAIS Terhadap Pelayanan Kopertais Wilayah XIII

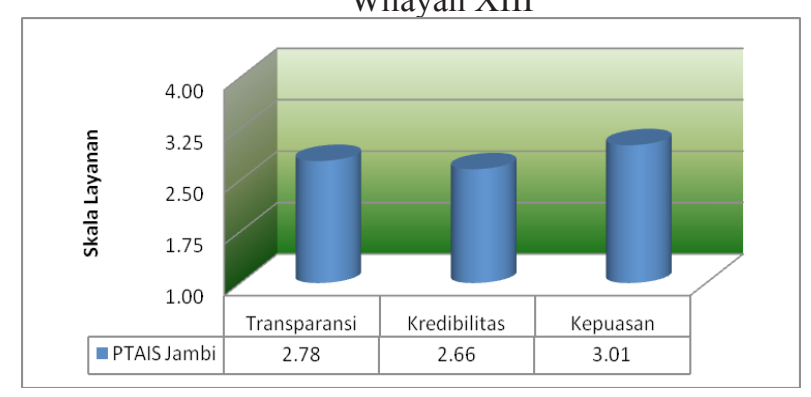

Sumber data: kuesioner yang diolah

Dengan demikian, jika ketiga variabel ini digabungkan untuk menilai kinerja Kopertais, maka diperoleh rerata 2,81 atau masuk kategori Baik diberikan PTAIS terhadap kinerja Kopertais Wilayah XIII. Berdasarkan grafik di atas, nampak terlihat bahwa secara keseluruhan mendapatkan rerata yang baik, tetapi nampak bahwa pada aspek kepuasan, Kopertais mendapatkan penilaian yang lebih tinggi dibandingkan kedua aspek yang linnya.

\section{PENUTUP}

Berdasarkan pada deskripsi dan pembahasan hasil penelitian di atas, maka dapat disimpulkan beberapa hal penting sebagai berikut: pertama, secara kelembagaan, Kopertais Wilayah XIII belum berdiri sendiri sebagai satuan kerja (satker) dan masih menginduk ke Satker IAIN Sultan Thaha Saifudin, sehingga berdampak pada terhambatnya perencanaan, pengelolaan, pelaksanaan dan pengendalian program kerja di Kopertais; kedua, sumberdaya yang mengelola atau memberikan pelayanan di Kopertais Wilayah XIII masih sangat jauh dari ideal, karena Kopertais Wilayah XIII ini memiliki tanggung jawab pengawasan, pengendalian dan pembinaan terhadap 15 PTAIS dengan 29 Program Studi yang tersebar di Provinsi Jambi.

Ketiga, pembiayaan program dan kegiatan Kopertais Wilayah XIII sampai saat ini masih "ditempelkan" atau dititipkan kepada DIPA IAIN Sultan Thaha Saifudin. Kondisi ini membawa konsekuensi pada minimnya jumlah anggaran yang dikelola untuk pelaksanaan fungsi pengawasan, pengendalian dan pembinaan yang dilakukan oleh Kopertais Wilayah XIII kepada PTAIS di Provinsi Jambi; keempat, sarana dan prasarana yang digunakan Kopertais Wilayah XIII sampai saat ini masih menumpang pada IAIN Sultan Thaha Saifudin. Ini berakibat saling tarik kepentingan antara pihak Rektorat dan pihak Kopertais.

Terlepas dari beberapa kekurangan yang masih "menyelimuti" kinerja Kopertais Wilayah XIII dalam melayani PTAIS, tetapi para pengelola PTAIS, masih menilai bahwa secara keseluruhan, layanan yang dilakukan oleh Kopertais Wilayah XIII masih termasuk kategori baik, karena upaya pengawasan, pengendalian dan pembinaan PTAIS masih tetap mereka terima. Namun demikian untuk peningkatam kualitas layanan Kopertais perlu melakukan terobosan terlebih dalam hal penjaminan mutu PTAIS.

Atas dasar temuan-temuan penelitian di atas, beberapa rekomendasi yang dapat disampaikan adalah sebagai berikut: Pertama, perlu segera dilakukan restrukturisasi kelembagaan Kopertais Wilayah XIII, dengan memberikan kepastian kewenangan, penganggaran dan eselonering pengelola Kopertais. Restrukturisasi ini dapat 
dilakukan dengan mengadaposi model struktur Kopertis yang berada di lingkungan Kementerian Pendidikan atau melakukan kajian eselonering dengan mempertimbangkan cakupan wilayah kerja dan beban kerja yang seimbang antar wilayah.

Kedua, mendesak dilakukan kajian tentang rasionalisasi jumlah pengelola Kopertais dengan jumlah PTAIS yang menjadi tanggung jawab Kopertais. Halinidiperlukanagarpelayananterhadap PTAIS dapat berjalan secara efektif dan efisien, serta fungsi pengawasan, pengendalian serta pembinaan PTAIS dapat diimplementasikan sesuai dengan regulasi yang ada; Ketiga, mempertimbangkan penyesuaian alokasi anggaran Kopertais Wilayah XIII secara proporsional berdasarkan cakupan wilayah kerja dan jumlah PTAIS di wilayah XIII Provinsi Jambi; Keempat, perlu dialokasikan anggaran khusus untuk penyediaan sarana dan prasarana Kopertais Wilayah XIII dalam rangka mendukung tugas dan fungsinya.

\section{UCAPAN TERIMA KASIH}

Pelaksanaan penelitian "Kapasitan Kopertais Wilayah XIII dalam Meningkatkan Mutu PTAIS di Provinsi Jambi" ini, mulai dari awal sampai penulisan laporan, tidak mungkin dapat terealisasi dengan baik jika tidak mendapatkan dukungan dari semua pihak. Oleh karena itu, kami sampaikan ucapan terimakasih atas kerjasama dan dukungannya, terutama kepada asisten peneliti yang telah membantu melakukan pengumpulan data dengan baik. Terima kasih juga disampaikan kepada Kepala Balai Penelitian dan Pengembangan Agama Jakarta yang telah memberikan support moril dan materil terhadap penyelenggaraan penelitian ini. Selain itu, dihaturkan terima kasih kepada semua pihak yang telah memberikan masukan, saran dan membantu secara teknis dalam penyempurnaan tulisan hasil ini. Tak lupa penulis haturkan terima kasih kepada redaktur Jurnal Al-Qalam yang bersedia menerbitkan tulisan ini.

\section{DAFTAR PUSTAKA}

Aditya, Muamar. 2010. Perhitungan Idle Capacity Dengan Menggunakan CAM-I Capacity Model Dalam Rangka Efisiensi Biaya Pada PT Bumi Tangerang Coklat Utama, Tesis. Jakarta: FE Universitas Indonesia.

Azwar, Saifuddin. 2000. Validitas dan Realibilitas. Yogyakarta: Pustaka Pelajar.

Badan Akreditasi Nasional Perguruan Tinggi (BAN-
PT). 2013. Standard dan Prosedur Akreditasi Perguruan Tinggi. Jakarta: Departemen Pendidikan Nasional.

Bappenas. 2002. Pedoman Penguatan pengamanan Program Pembangunan Daerah. Jakarta: Depdagri.

Barata, Atep Adya. 2003. Dasar-dasar Pelayanan Prima. Jakarta: Gramedia.

Bungin, Burhan. 2010. Penelitian Kualitatif. Jakarta: Kencana Prenada Media Group.

Creswell, John W. 2008. Research Design: Qualitative, Quantitative and Mixed Methods Approaches. California: SAGE Publications Inc.

Hardjana, Andre. 2000. Audit Komunikasi Teori dan Praktek. Jakarta: PT Grasindo.

Norman K. Denzin dan Yvonna S. Lincoln (Eds). 1994. Handbook of Qualitative Research. Thousand Oaks, California: SAGE Publications.

Keputusan Direktur Jenderal Pendidikan Islam Nomor: Dj.I/494/2007 Tentang Tugas, Fungsi, dan Mekanisme Kerja Koordinatorat Perguruan Tinggi Agama Islam Swasta.

Keputusan Menteri Negara Pendayagunaan Aparatur Negara (Meneg PAN) Nomor 63/KEP/M.PAN/7/2003 Tentang Pelayanan Publik.

Kopertais Wilayah XIII. 2012. Laporan Statistik 2012.

Kopertais Wilayah XIII. 2012. Pedoman Akademik tahun 2012-2013.

Kopertais Wilayah XIII. 2012. Profil Kopertais Wilayah XIII Jambi.

Mardiasmo, 2004. Otonomi dan Manajemen Keuangan Daerah, Yogyakarta: Andi.

Peraturan Dirjen Pendis Nomor: DJ.I/814/2010 Tentang Kode Etik Pegawai.

Peraturan Pemerintah Nomor 60 Tahun 1999 Tentang Pendidikan Tinggi.

Purwadarminta, 1976. Kamus Umum Bahasa Indonesia. Jakarta: Balai Pustaka.

Pusat Bahasa Depdikanas. 2003. Kamus Besar Bahasa Indonesia, Edisi Revisi, Cetakan Ke-3. Jakarta: Balai Pustaka.

Rahman, Meutia Ganie. 2000. Good Govermance, Prinsip, Komponen dan Penerapanya dalam Hak Asasi Manusia. Jakarta: Komnas HAM

Rakhmat, Jalaluddin. 2004. Metode Penelitian komunikasi. Bandung: PT. Remaja Rosdakarya.

Tilaar, H.A.R. 1997. Pengembangan Sumber Daya 
Manusia dalam Era Globalisasi. Jakarta: http://www.ranking-ptai.info/Lbg\&Fak\&ProPtai/ , Grasindo.

Winardi, Manajemen Perilaku Organisasi. 2007. Jakarta: Prenada Media Group.

Undang-undang Nomor 2 tahun 1989 Tentang Sistem Pendidikan Nasional.

Undang-undang Nomor 20 Tahun 2003 Tentang Sistem Pendidikan Nasional.

Internet : diakses pada tanggal 04 Juni 2013.

http://kbbi.web.id diakses pada tanggal 4 Juni 2013. http://uin-malang.ac.id/index.php?option=com content\&view=article\&id =3016: problemperguruan-tinggi\&catid, diakses pada tanggal 4 Juni 2013.

Sumber Informasi

Hadri Hasan (Koordinator Kopertais Wilayah XIII), Wawancara, pada tanggal 6 Juli 2013.

Maryadi Syarif (Puket I STAI Ahsanta Kota Jambi), Wawancara, pada tanggal 15 Juli 2013.

Mawardi Sadim (Ketua STAI SMQ Bangko), Wawancara, pada tanggal 10 Juli 2013.

Musthafa (Puket II STAI Muara Bulian), Wawancara, pada tanggal 13 Juli 2013.

M.Saman (Ketua STIT Darul Ulum Sarolangun), Wawancara, pada tanggal 8 Juli 2013.

Nawawi (Kabag Bina PTAIS) Wawancara, pada tanggal 6 Juli 2013. 